\title{
A Small Special Needs Class or a Smaller Class at the Beginning of the Educational Path?
}

\author{
Raine Valli \\ Kokkola University Consortium Chydenius \\ E-mail raine.valli@chydenius.fi
}

KatjaJokinen

City of Vaasa

E-mail katja.jokinen@edu.vaasa.fi

Received: March 31, 2016 Accepted: April 15, 2016 Published: May 1, 2016

doi:10.5296/jse.v6i2.9236 URL: http://dx.doi.org/10.5296/jse.v6i2.9236

\begin{abstract}
This article is based on the case study which focuses on the small class (in this article used to describe a small special needs class) operation of one medium-sized Finnish town. In the study an attempt was made to clarify what kind of alternative the small class is to the first grade of general education at the beginning of the child's educational path, what kind of experiences the teachers had of the pupils of the small class, of multi-vocational cooperation and of pupils' integration and success in general education. The results of the study showed that a large part of the pupils who come to the small classes had learning difficulties, and attention and behavioural disorders. If the children in need of support would receive it already during pre-school education, most of them could start their school directly in the first grade in general education.
\end{abstract}

Keywords: I21 Analysis of Education, I31 General Welfare; Basic Needs; Quality of Life, I00 General 


\section{Early intervention prevents social exclusion}

Finland's success is excellent in the PISA comparisons, year after year. It is being said that Finland is the best place in the world to live, which is significantly affected by our school system as one factor. (Välijärvi \& Heikkinen 2012, 31-32.) Still, in Finland one has to think carefully how the special needs education is arranged. Its success is eventually significant for the success of the whole society since every individual has to obtain productive work; a meaningful and productive role has to be found for them. In Finland the number of pupils with special needs has increased in the last ten years. Over 46710 pupils, in other words 8,5 percent of the pupils in basic education were taught in special needs education in 2010. The number has increased rapidly, as ten years ago the number was still about 20 000. (Statistics Finland 2010; Teittinen 2003.) The numbers in the transfers to special needs education have clearly increased and large differences can be found between the different municipalities. The increase has been affected by statistical factors and those of rehabilitation and treatment, advanced diagnosis, new information received from special needs pedagogical research and changes in the educational legislation. (Cohen 2006; OPM 2007.) The latest subject that has provoked discussion has been a change in the Basic Education Act (642/2010) in accordance with the government program of Ministry of Education and in which the Basic Education Act concerning special needs education was changed. It changed the arrangements of the special needs education in a way that the decision concerning the pupils' special needs support will be fixed-term in the future. It is drawn up for no more than two years at a time, unless a clear need, such as a disability, is a basis for the decision for special needs education. The decision can be made during the pre-school education or during grades 1-2. It is administrative and it can be appealed. The HOJKS (=the personal plan concerning the arranging of the teaching) that is drawn up for the pupil cannot be appealed and it is a pedagogical document in the future. (Basic Education Act 642/2010, 17a §.)

The small class means providing education in the smaller, familiar group in which special needs support is offered. The small class operation is not merely the teaching of the pupil, educating and sharing of information, but also taking individuality into consideration and multi-vocational cooperation with parents and with different quarters of society. In the long term the small class operation can be the prevention of the social exclusion of the pupil. To many pupils, the small class is a kind of diagnostic year whilst considering their future education. Early identification of special needs and tackling the problems are important.

In Finland children start school during the year they turn seven. The basic education lasts for nine years, but it is preceded by one pre-school year. The aim has been to create a comprehensive school for the whole age group, which is based on the idea of the compulsory school available to all children. The principles are equal access to education and guaranteeing equal educational opportunities for all the pupils in the comprehensive school. Basic education in Finland is free of charge, and provides general education for all the pupils.

The practice is that the pupils in the 1-2 grade in the small class are integrated as soon as possible into the other 1-2 grade classes. Earlier research results of the integration vary for and against. (See Skårbrevik 2005; Naukkarinen 2005; Haapaniemi 2003; Kuorelahti 2000; 
Kauffman 1999.) If necessary, the pupil can stay in the small class for the whole time they are in the 1-2 grades. However, the objective is to move permanently to a class in general education at the latest after grades 1-2.

In this article we search for the answer to the question: How has the studying in the first grade of general education succeeded in the small class? According to research results, the problems in learning experienced by the pupils suffering from a wide range of learning difficulties begin to be seen in the middle childhood, in other words especially during the 8-12 years of age, the reason for this being the growing demands in the school. The problems accumulate when the internalization of the new information requires mastering earlier skills and knowledge. The problems are usually seen as weak school grades, among others, and in the worst case the final result can even be the discontinuation of the whole comprehensive school (Lämsä 2009; Dyson, Farrwel, Polas, Hutcheson \&Gallannaugh 2004). According to Korkeamäki $(2002,83)$ the school performance is later complicated particularly by the shortcomings in the academic skills during the child's first school years. (See also Linnilä 2006.) The operational culture of the whole school probably has to change so that all the pupils could begin their educational path in their local school in the grades 1-2 in general education or in a small class.

\section{The ones needing the support go to the support}

Saloviita $(2003,13)$ emphasizes that the special needs teaching is never a place but a support which can be offered also in an ordinary class. In his opinion, the pupil does not need to transfer to the special needs education but the special needs teaching can come to them. The thematics of equality and of the positive special treatment are essential when special needs education is examined. In school, it requires taking into consideration the pupils' individual starting points, developing the different measures of support and accessibility and promoting the inclusion of all the pupils. (Liston \& Garrison 2004; Wilson 2003, 25.) Mikola (2011, 18-19) states in her doctoral thesis that the change in technology, multiculturalism, common solutions to the global problems, changing conceptions of learning and the objective of an inclusive school set new tasks for the basic education, which our educational system has to be able to answer.

The special needs education of the comprehensive school follows the basis and principles of the ordinary school in its education. The special needs education has for a long time leaned on the disability's individual or medical model, in which the lack of special needs education is based on the medical diagnosis. (Emanuelsson \& Persson 1997, 127). The idea of the disability has changed gradually from medical thinking which separates different disability groups into their own sectors towards the social interpretation of disability, in which attention is paid to the problem areas of the school and the community instead of the attributes of the individual (Adams, Clark \& Swain 2000, 243; Barton 2003, 58-59.)

The number of the pupils with special needs is increasing continuously. Some of them are in the part-time special needs education, in which case they attend the general education in part. In Finland the general education and the special needs education have been separated from each other; in other words the dual system is in use in the comprehensive school. Due to the dual system, the school organization, the structures and history have formed accordingly. The 
Finnish teacher education is also based on the fact that the general education and the special needs education are separate systems. This is also seen at the municipality level of the school administration. Separate staff work in the general education and in the special needs education, and they have separate school premises. The ones needing support still often go to the support, rather than the support services to the pupils. (Naukkarinen 2002, 346.)

Segregation is often interpreted as an opposite of integration. In secregation, the pupil who has special educational needs is dismissed, in other words segregated from the general education. At day nursery and at school the specification of the special need is based on the individual model of disability, which is based on the medical diagnosis which includes the idea of placing the problem with the individual. At the same time it produces and maintains the children's classification as non-normal (Barton 2003, 58-59; Pöyhtäri 2010, 149.)

According to the studies, the investment in special needs education does not always guarantee more intensive teaching than general education for the pupil (Kauffman \& Pullen 1996, 6-7; Kuorelahti 2000.) Kauffman (1999) and Martin (1997) emphasize that some of the pupils who have learning difficulties could study also in the general education with sufficient support services. However, they state that teaching of all the pupils who suffer from learning difficulties cannot be organized in the general education because the mere physical participation in the general education does not guarantee an educational inclusion. So the inclusion can sometimes prove to have obstacles for educational reasons. Then one can think that the expectations set for the teaching are not always bound to the realities. (Kauffman 1999, 6-7; Mart 1997, 232-235.) Many pupils get excellent teaching in the special needs classes, but most get only what they would get in the general education class or even less according to Kauffman and Pullen $(1996,2)$. According to several studies the segregated environments are harmful academically, socially and from the point of view of the choice of a career. In this kind of an atmosphere both the educator and the pupil have a pessimistic perception in regard to their learning and their future. Indeed, segregation often leads to a pupil's weak self-esteem and to the spiral of social exclusion according to the studies. (Puro 2005, 82; Dyson etc. 2004; Stainback\&Stainback 1997, 4-6.)

According to Moberg (1998, 155-158), the integration always requires the acceptance and commitment of the people, especially the teachers, who carry out and have an effect on the teaching. If the teachers are excited about the integration, they provide the proper necessary conditions for the good teaching of the pupils who need special needs education. (See also Menlove, Hudson \& Suter 2001, 29-30.)

The Saloviita $(1998,19)$ points out that Finland has agreed with the international proclamations of carrying out of the equality in the education. Because the objective of the integration is one common school system, it has to serve everyone who is to be educated well. One school must be able to take into consideration the educational needs and of the ones to be educated; in other words the aim is to combine special needs education and general education. Naukkarinen $(2005,9)$ states that Finland's school statutes and laws are mainly integration affirmative. The same trend can be seen also in other parts of Europe, even though the political line has been the integration of the pupils who need special needs education into 
the schools of general education and offering different forms of support to the teachers. However, the majority of the pupils who belong to the sphere of special needs education do not study in the general education together with other pupils. (Meijer, Soriano \& Watkins 2003, 7; Mackinnon, Newbould, Zeldin \& Hales 1997.)

Moberg (1996, 121-126) suggest that every pupil should receive their education in that general basic education group to which the pupil belongs because of their age. However, Moberg does not exclude the use of different support services outside the basic education group. According to Ahvenainen etc. $(2002,111)$ in an inclusive class community there should be support services also in the general education environment for the use of the pupils. When the pupil needs adjusted teaching, in other words individualized teaching and special methods or equipment to succeed in their studies or in social relations, the services are brought to the general education environment and not to the special needs education. So the pupil does not need to seek their way to the services outside the school but the pupil's needs have to be satisfied in an existing and normal class community.

The Saloviita $(2006,340)$ defines inclusion as the opportunity for all the pupils, including special needs pupils, to receive participatory education. In turn, the participatory education is a characteristic of the inclusion that is seen as a community spirit, both in the classes and in the operational culture of the school. The fight for the inclusive school continues and the people are still segregated and excluded especially during the school years (Peterson \& Hittie 2003, 11). Researchers criticizing inclusion see that when many special needs pupils are placed in the same general education class, the realisation of the objectives of the general education becomes more difficult. (Saloviita 2006.) In order to reach the objectives, a class size should be reduced at the same time. Lehtomäki and Takala $(2005,97)$ stress that the special needs education has been criticized because it labels the pupils as abnormal and different. In inclusion the difference is an essential part because we are all different.

In integration the learner will at some stage become part of general education according to Stainback and Stainback (1997, 26-31), but in inclusion the learner is in the general education from the beginning. Inclusive development needs to be invested in because only then can it take root as a part of basic education. The objective is high-quality pedagogics, which benefits all the learners. (Sindelar, Shearer, Yendol-Hoppey \& Liebert 2006, 317-320.)

The focus in special needs education has switched from the end of the 1960s from a special needs school and special needs classes to the classless and part-time special needs education (Kivirauma 1989, 189). Nowadays, the forms of implementing the special needs education can be divided into simultaneous teaching (more than one teacher working with the group), part-time special needs education, class-type special needs education, in other words into full-time special needs education and into other special needs education such as hospital education or home schooling. The transition to the special needs class or to the special needs school can only take place after the pupil has first been offered intensive support in the general education. If the provided support is not enough, the decision of special needs support will be made for them, which requires the pedagogical statement made by the multidisciplinary pupil welfare team. 
Time will tell whether the transferrals to the special needs classes will diminish with the new law change (2010) concerning special needs education, because the pupil must be offered intensive support before the decision of the special needs support is made. As has been presented above, the special needs pupils' teaching can be arranged in many ways. In this article small group teaching is examined, in which case the special needs pupils work in their own separate group as a rule, but their partial integration is begun at as early a stage as possible and the objective is to transfer them completely to general education.

\section{Special needs education as a form of support}

The children's difficulties in learning and adapting can be quite reliably perceived already at the pre-school age and they may reflect in the children's achievements during the whole length of their school attendance. Pulkkinen (2002) emphasizes that attention has to be paid already to the special needs education of the pre-school. The significance of the intensive pre-school education especially during the pre-school year seems to be a recommended procedure instead of a school postponement and instead of a so-called start class (a small class for the children whose school start has been postponed by a year) because the difficulties can be usually seen already before starting the school. Dealing with the difficulties already during the pre-school year produces better results than postponing the starting of school, because offering the support already in the pre-school education also promotes the child's possibilities to proceed in the education with their own age group (Pulkkinen 2002, 101-102). Also according to the study by Alijoki (2006) some of the children who need special needs support, needed support at least for the whole pre-school education and in grades 1-2 in general education. On the other hand, the research results showed that of the children who had received the special needs support for the whole pre-school year, some were able to participate in general education already during grades 1-2.

Voutilainen, Häyrinen and Iivanainen $(2000,12)$ state that $10-15$ percent of all the children have learning difficulties. Of them 2,5-5 percent have severe learning disorders. According to Ikonen, Juvonen and Ojala $(2002,30)$, as many as 20 percent of the age group have some level of learning difficulties. Learning difficulties are one of the most central risk factors (see Farrell 2000, 48) that threaten the child's development. Kaplan, Wilson, Dewey and Crawford (1998) noticed in their studies that about half of the children who had difficulties in reading also had difficulties in motor learning. It is estimated that altogether about 20 percent of the children have developmental motor disorders.

Attention deficit hyperactivity disorder (ADHD) in turn is a matter of the child's difficulty to regulate their operation and behaviour according to a task, environment or according to their own objectives. Attention deficit disorder is strongly connected with adequate and fluent interaction with others and with the skills required by the interaction in regulating feelings and behaviour. (Myllykoski, Melamies \& Kangas 2004, 12.)

A pupil with a behavioural disorder brings his/her own additional challenge to creating the learning environment of the class, in creating the atmosphere and in maintaining a peaceful working atmosphere. The school should be able to take into consideration the pupil as an individual and should be able to set him the expectations that are realistic enough. The 
interaction should be consistent and the teaching functional. Instead of punishment, positive feedback should be given and the pupil should be encouraged. The adult should serve as a good model and show that they care for the pupil (Kauffman 2001, 72).

This study has been limited to the examination of these three factors (the learning difficulties, attention disorders and behavioural disorders) because these factors which make learning more difficult affect the pupils in the target group of the study. However, one must state that special needs education is a wide field which makes it extremely important that the teachers are highly trained, skilled professionals, special needs teachers who identify the pupil's difficulties and can look for the right measures for them.

\section{The research tasks and the material}

This article is based on a qualitative case study in which the small class operation is one form of special needs support of the comprehensive school. According to Metsämuuronen (2000, 18) a case study can be understood as the central strategy of acquiring information in the qualitative methodology because nearly all qualitative studies are case study. The starting point for it is the individuals' ability to interpret the events of human life and to form significant interpretations of the world in which the people operate. (See Gomm, Hammersley \& Foster 2000, 2-5; Yin 2003, 13.) It is characteristic to a case study that the material is collected over a long period of time and from several points of view, when an attempt is made to examine the case from many sides.

This research consisted of the following materials: theme interview with three special needs class teachers, four class teachers' written accounts, a questionnaire for the fifteen former small class pupils and a theme interview with two principals and two people in the education board management. The material has been collected from the small class operation of one medium-sized Finnish town (Vaasa). The material was collected over a period of three years. We focus on the examination of the following question in this article: How has the studying in the first grade of general education succeeded in the small class?

\subsection{Analysis of the material}

In the analysis of the material qualitative methods were used, by means of content analysis, which is a method that can be used to examine the connections and effects of the data. It is based on interpretation and inferences proceeding from the empirical material towards a more conceptual view of the phenomenon to be examined. In the analysis, abductive reasoning was used. According to Hakkarainen, Lonkka and Lipponen (2004, 322-238), abductive reasoning makes the perceived phenomenon more intelligible in certain situations and offers an explanation of the reason without proving it true. In this material, abductive reasoning has occurred relying on the practical and theoretical background information. In this research, the conceptions of inclusion, integration and segregation form the background information (Cf. Glaser \& Strauss, 1967.)

\section{Results}

The objective of the study was to gather evaluation information of the implementation of 
small class operation and from the basis of the descriptions and interpretations concerning the context of the research subject and the significances given to the phenomena by the participants. The aim was also to study the small class operation and to examine the consequences of the operation, to make the interpretations and suggestions to develop the operation.

\subsection{Selection of pupils and how they work}

In Vaasa, stabilizing of the small class operation and establishing of new classes to the elementary schools have made the pupils' transition to the special needs units possible. The trend has been distinctly segregative. According to this research, a large proportion of the pupils of small classes have learning difficulties or an attention disorder. However, the teachers consider the pupils with behavioural disorders the most challenging. Pupils, whose school start has been postponed by a year, most often for social-emotional factors, come to the small classes every year. According to the teachers, the child should also get support in the area of emotions. For this reason it would be good in the teachers' opinion for the children with school postponement to remain in the day nursery, learning social skills.

It has been stated in a number of studies that transferring pupils with immigrant backgrounds to special needs education is more common when compared with the mainstream (Laaksonen 2009; Harry \& Klingner 2006; Crockett \& Kauffman 1999). Also in Vaasa, the number of immigrant children has increased every year. This is evident in all the schools, as it is in the special needs classes. According to the teachers, multiculturalism can be seen in the everyday life of the school as the wide range of nationalities, race, home languages and religions as well as other cultural practices of the pupils. Identifying the possible learning difficulties of immigrant pupils and taking into account the cultural and language backgrounds in teaching have brought challenges to teaching according to the teachers. The immigrant pupils who have been selected for the small classes have received the special needs support they need from the qualified special needs teachers.

In Vaasa some of the pupils of small classes integrate immediately in the lessons in general education classes during the autumn of the first school year. The most common lessons for integration are the arts subjects. The integration takes place individually in the classes in general education. According to the teachers, it is easiest to integrate a pupil who behaves calmly and is attentive in the lessons.

The child with a behavioural disorder is the most problematic. For certain special needs children one must state that the teacher must have the professional skill of the special needs teacher in the class to manage.

The transition to the bigger class is often challenging for the pupil. The teaching speed can be quicker and asking for help requires courage. In the class there can also already be pupils who need special needs support which requires additional resources and sets bigger pressures for reaching the learning objectives. The class teachers take a pupil from the small class to their class willingly if they get an assistant for the lessons. The teachers hoped for smaller class sizes so that the cooperation between the classes would become easier. 
In this material both the teachers and the principals emphasize the significance of the working partners when integrating a pupil into general education is considered. Also the simultaneous teaching is considered as important for the pupils and teachers to get to know one another. In that case both the class teacher and the special needs teacher will become acquainted with each other's pupils simultaneously, with the additional advantage that there are more adults to help in the lesson at the same time.

The former pupils of the small class highlighted a small group size, a peaceful atmosphere, an identification of learning problems and strengths and the sufficient advise and help from the teacher in the lessons as the advantages of studying in a small class. The teacher had more personal time for each child. The teachers of the small class had been perceived as nice and as reliable experts. The assistants had also been liked.

"The assistant is also a working partner who can support the teacher. It is not necessary to think and explain the whole story in practical situations. Four eyes can see better, whatever takes place".

According to the pupils, the constant noise experienced in the small class had been disruptive and the accumulation of the inattentive pupils to small classes had made concentrating more difficult. Making friends from their own class had been difficult for the girls because boys were in the majority in classes. A few pupils had experienced teasing whilst in the small class and when moving on from there. In the pupils' opinion, the teachers had of course tried to intervene in the teasing.

According to Kuula (2000), the pupils should not get negative school experiences because they form into a spiral which feeds itself. This in turn increases a negative attitude towards the school, it lowers self-esteem and belief in the pupil's potential to manage. Eventually they promote social exclusion. Kuorelahti (2000) states that individuality in particular is the cornerstone of special needs education. One should indeed talk about individual learning and teaching, about encouraging teachers and about taking the risks when developing teaching.

\section{Transferring from the small class into general education}

Transfers of students from a small class to a class in general education are case specific and thus individual for every pupil. The pupil can transfer already after the first grade but it will take place more often only after the second school year has ended. The majority of the parents hoped that their child was able to move permanently to general education already after the first year in the small class. However, the class teachers considered it important that the pupil would not move too early to general education because they may have gaps in their knowledge and skills or that their social skills have yet not developed.

"He should move to my class completely next year but I am afraid in advance about whether he can manage with the rest of the class. It would surely be sensible if he could continue still for one more year in the small class, at least in the teaching of mathematics and the mother tongue”.

The special needs class teachers' experience that they are responsible for how the pupils who 
have moved from the small class succeed in general education. However, according to them the success is ultimately dependant on the teachers who work with the child. The teachers indeed emphasize the significance of transferring information when the pupil moves to the class in general education from the small class and from the elementary school to the upper school. Likewise, the learning environment and the support services should be well designed, continuing the whole duration of study.

After moving from the small class the second transitional stage is moving from the elementary school to the upper school. The class teachers expressed in their writings particularly, this worry of the former pupils of the small class moving from the elementary school to the upper school. They hoped the pupils would get support during this transitional stage and also still at upper school. Exchanging information is important also at this stage between the class teacher, the teacher responsible for the class, the special needs teacher and the parents. At both transitional stages, exchange of information between the teacher groups and cooperation with the multi-vocational cooperation networks is highlighted.

"When they are now moving to the upper school, my biggest worry is whether they will manage there. Every one of them would need some kind of support, in my opinion".

According to the teachers' experience, the pupils' learning difficulties do not seem to disappear even at the higher grades of the elementary school, so they should be dealt with systematically during their whole time in school.

\subsection{Attitude towards the pupil}

According to the questionnaire directed to the pupils, a few pupils of the small class had experienced teasing and being labelled after the transition from the small class. The teasing had been mainly name-calling. In earlier studies it has been stated that the pupils who study in the special needs classes are teased often, which becomes poignant also in this study. The reason is usually a status of studying in the special needs class and getting labelled because of being a different type of learner. (See Hamarus 2009, 134; Niemi, Mietola \& Helakorpi 2010, 77, 89). According to the principals who were interviewed, the pupils of the small class being labelled as special needs pupils is not usually seen in the small classes. It is not seen in the pupils' or the parents' attitudes.

"If the children do not notice the difference in a pupil or in a class, how can one imagine that parents would notice the difference in the small class compared to other classes?”

However, the placement in the small class is not always easy. In the interview, the management of the education department tells about the pre-school children's parents who begin to hesitate often at the stage when the small class option is being offered as a place to start school.

The significance of a local school, which also affects the prevention of social exclusion, became one important result of this study. It is important to develop the principle of the local school because in it the objectives of inclusion are realised. These is the basic principle of inclusion: all the pupils are different and they can learn, the communities create diversity and 
diversity can and must be appreciated. The objective of inclusion is also the promotion of human rights, social fairness and equality and the promotion of the positive attitudes and of social relations. (See Kivirauma, Rinne \& Klemelä 2004; Thomas \& Vaughan 2004.)

\section{The future of small classes}

A small class in the grades 1-2 of general education can also be one solution in the future for the pupils who need special support at the start of their educational path, because the small group size seems to provide a greater possibility that the special needs class teacher has more time per pupil in the lessons (Skårbrevik 2005.) For the special needs education to be of high quality, many matters must succeed: the cooperation between home and school to work, the integration to be realized, the assistants to be trained, the leadership to be supported, the different teacher groups to co-operate among themselves, the teaching to be target-oriented, the interaction to work, the schools to have sufficient resources and all the teachers to have good professional skills. (Hotulainen \& Takala 2008, 43.)

So far the model of the so-called flexible education in the grades 1-2, in which the small class has cooperated more closely than before with the parallel classes, has been tested in a few elementary schools. This trend is promising because then the pupil's stigma as a special needs pupil disappears, which proved to be a pressing memory also in this research material. In the future it would be good to think of ways of offering the special supports that are more inclusive, and less labelling ways to carry out teaching. It is good to remember that the early measures that prevent and smooth out problems such as the small class teaching, will become considerably cheaper than dealing with those problems later. Social exclusion of children and adolescents begins ever earlier and earlier so the intervention and the prevention of it are a challenge for the whole of society.

\section{References}

Adams, J., Clark, J., \& Swain, J. (2000). What's So Special? Teachers' Models and Their Realisation in Practice in Segregated Schools. Disability \& Society, 15(2), 233-245. http://dx.doi.org/10.1080/09687590025658

Aho, S., \& Laine, K. (1997). Minä ja muut. Kasvaminen sosiaaliseen vuorovaikutukseen. [Me and others. Growing for the social interaction]. Helsinki: Otava.

Ahvenainen, O., Ikonen, O., \& Koro, J. (2002). Introduction to the practice in the special needs education.[Johdatuserityiskasvatuksenkäytäntöön]. Helsinki: WSOY.

Alijoki, A. (2006). The paths of the children in need of special needs support from pre-school to the grades 1-2 in general education - forms of support and performance. [Erityistä tukea tarvitsevien lasten polut esiopetuksesta alkuopetukseen - tukitoimet ja suoriutuminen]. Väitöskirja. Helsingin yliopisto, Käyttäytymistieteellinen tiedekunta. Soveltavan kasvatustieteen laitos.

Barton, L. (2003). The politics of education for all. In M. Nind, J. Rix, K. Sheehy \& K. Simmons (eds.) Inclusive education: Diverse perspectives. London: David Fulton Publishers Ltd, 57-64. 
Cohen, D. (2006). Critiques of the “ADHD” enterprise. In G. Loyd, J. Stead \& D. Cohen (eds.) Critical new perspectives on ADHD. London \& New York: Routledge, 12-33.

Crockett, J. B., \& Kauffman, J. M. (1999). The least restrictive environment.Its origins and interpretations in special education. London: Lawrence Elbaum Associates.

Dyson, A., Farrwel, P., Polat, F., Hutcheson, G., \& Gallannaugh, F. (2004). Inclusion and pupil achievement.Department for Education and skills. Research Report No 578. University of Newcastle.

Emanuelsson, I., \& Persson, B. (1997). Who is considered to be in need of special education: why, how and by whom? European Journal of Special Needs Education, 12(2), 127-136. http://dx.doi.org/10.1080/0885625970120204

Farrell, M. (2000). The special education handbook. London: David Fulton Publishers.

Glaser, B. G., \& Strauss, A. L. (1967). The discovery of grounded theory. New York: Aldine de Gruyter.

Gomm, R., Hammersley, M., \& Foster, P. (2000). Case study method. Key Issues, key texts. London: Sage.

Hakkarainen, P. (2002). Varhaiskasvatus ja tieteellinen tutkimus. Kasvatus [Education], 33(2), 133-147.

Hakkarainen, K., Lonka, K., \& Lipponen, L. (2004). Tutkiva oppiminen. Järki, tunteet ja kulttuuri oppimisen sytyttäjinä. [Investigative learning. Reason, emotions and culture in igniting the learning]. Helsinki: WSOY.

Hamarus, P. (2009). Miten estää koulukiusaamista? In T. Saloviita (eds.) Meidän koulu. Keinojatyörauhanjahyvänilmapiirinsaavuttamiseen. [Our school. Ways for reaching good and peaceful working atmosphere]. Jyväskylä: PS-kustannus, 129-144.

Harry, B., \& Klingner, J. (2006). Why are so many Minority Students in Special Education? Understanding Race \& Disability in Schools. New York: Teachers College Press.

Hautamäki, J., Lahtinen, U., Moberg, S., \& Tuunainen, K. (2002). Erityispedagogiikanperusteet.[The foundations of special needs education]. Helsinki: WSOY.

Hotulainen, R., \& Takala, M. (2008). Helsingin erityisopetuksen laatua arvioimassa. [Evaluating the quality of specialneeds education in Helsinki]. Helsingin kaupungin opetusviraston julkaisusarja A1. Helsinki: Edita Prima Oy.

Ikonen, O., Juvonen, J., \& Ojala, T. (2002). Oppimisesta, opettamisesta ja oppimisvaikeuksista. [Of learning, teaching and learningdifficulties]. In O. Ikonen, J. Juvonen \& T. Ojala (eds.) Kohtaamisia koulupolulla. Kasvun ja oppimisen tukeminen. Jyväskylä: PS-kustannus, 22-40.

Kaplan, B. J., Wilson, B. N., Dewey, D., \& Crawford, S. G. (1998). DCD may not be a discrete disorder. Human movement science, 7(4-5), 471-490. 
http://dx.doi.org/10.1016/S0167-9457(98)00010-4

Kauffman, J. M. (1999). Commentary. Today's special education and its messages for tomorrow. Journal of Special Education, 32(4), 244-255. http://dx.doi.org/10.1177/002246699903200405

Kauffman, J. M. (2001). Characteristics of emotional and behavioural disorders of children and youth. New York: Prentice Hall.

Kauffman, J. M. (2008). Would we recognize progress if we saw it? A commentary. Journal of Behavioral Education, 17(1), 128-143. http://dx.doi.org/10.1007/s10864-007-9060-z

Kauffman, J. M., \& Pullen, P. L. (1996). Eight myths about special education. Focus on Expectional Children, 28(5), 1-13.

Kivirauma, J. (1989). Erityisopetus ja suomalainen oppivelvollisuuskoulu vuosina 1921-1985. [Special needs education and Finnish compulsory school during 1921-1985]. Väitöskirja. Turunyliopistonjulkaisuja C 74.

Kivirauma, J. (1998). Normaali erityisopetuksen piilo-opetussuunnitelmana. [The normal hidden curriculum in special needs education]. In T. Ladonlahti, A. Naukkarinen\& S. Vehmas (eds.) Poikkeava vai erityinen? Erityispedagogiikan monet ulottuvuudet. Jyväskylä: Atena Kustannus, 203-215.

Kivirauma, J., Rinne, R., \& Klemelä, K. (eds.) (2004). Erityisopetus laajenevana koulutienä. Turkulainen erityisopetus oppilaiden, vanhempien ja opettajien kokemana. [Special needs education as the widening route to school. Special needs education in Turku as experienced by the pupils, parents and teachers]. Turun yliopisto. Turun yliopiston kasvatustieteiden tiedekunnan julkaisuja A: 203.

Korkeamäki, R.-L. (2002). Lukemaan oppiminen edellyttää mielekkäitä tekstejä ja aktiviteetteja. [Learning to read requires meaningful texts and activities]. In O. Saloranta (eds.) Ensimmäiset kouluvuodet. Perusopetuksen vuosiluokkien 1-2 opetus. Helsinki: WSOY, $75-85$.

Kuorelahti, M. (2000). Sopeutumattomien luokkamuotoisen erityisopetuksen tuloksellisuus. [The effectiveness of special needs class education of the maladjusted]. Väitöskirja. Jyväskylä studies in education, psychology and social research 169. Jyväskylänyliopisto.

Kuukka, I., \& Agge, K. (2009). Vaihtoehtoja erityisopetukselle. [Alternatives to special needseducation]. In L. Nissilä \& H.-M. Sarlin (eds.) Maahanmuuttajien oppimisvaikeudet. Keuruu: Otava, 99-112.

Kuula, R. (2000). Syrjäytymisvaarassa oleva nuori koulun paineessa. Koulujanuortensyrjäytyminen. [Adolescent at the risk of exclusion in the pressures of school. School and the social exclusion of adolescents]. Väitöskirja. Joensuun yliopiston kasvatustieteellisiä julkaisuja n:o 61.

Laaksonen, A. (2009). Maahanmuuttajaoppilaiden kokemuksia perusopetuksen erityisestä 
tuesta erityiskoulussa Suomessa. Teoksessa L. Nissilä \& H.-M. Sarlin (toim.) Maahanmuuttajien oppimisvaikeudet.

Lehtomäki, E., \& Takala, M. (2005). Kohti inkluusiota? [Towards inclusion?] In E. Lehtomäki \& M. Takala (eds.) Kieli, kuulo ja oppiminen - kuurojen ja huonoluuloisten lasten opetus. Finn Lectura, 97-104.

Linnilä, M.-L. (2006). Kouluvalmiudesta koulun valmiuteen. Poikkeuksellinen koulunaloitus koulumenestyksen, viranomaislausuntojen ja perheiden kokemusten valossa. [From school readiness to the school's readiness.Irregular school start in the light of school success, professional statements and experiences of the families]. Väitöskirja. Jyväskylä Studies in Education, Psychology and Social research 294. Jyväskylänyliopisto.

Liston, D., \& Garrison, J. (2004). Teaching, learning and loving. Reclaiming passion in educational practice. New York: RoutledgeFalmer. http://dx.doi.org/10.4324/9780203465622

Lämsä, A.-L. (2009). Tuhat tarinaa lasten ja nuorten syrjäytymisestä. Lastenjanuortensyrjäytyminensosiaalihuollonasiakirjojenvalossa. [One thousand stories of social exclusion of children and adolescents. Social exclusion of children and adolescents in the light of social services' documentation].Oulunyliopisto 2009.http://herkules.oulu.fi/isbn9789514290213/isbn9789514290213 (Read 19.7.2009)

Mackinnon, D., Newbould, D., Zeldin, D., \& Hales, M. (1997). Education in Western Europe.Facts \& Figures. The Open University.

Martin, D. S. (1997). Inclusion: Time to Rethink. The Educational Forum 61: 232-239. http://dx.doi.org/10.1080/00131729709335260

Meijer, C., Soriano, V. \& Watkins, A. 2003. European Agency for Development In Special Needs Education.

Menlove, R. R., Hudson, P. J., \& Suter, D. (2001). A Field of IEP Dreams. Teaching Exceptional Children, 33(5), 28-34. http://dx.doi.org/10.1177/004005990103300504

Mikola, M. (2011). Pedagogista rajankäyntiä koulussa. Inkluusioreitit ja yhdessä oppimisen edellytykset. [Pedagogical demarcation in the school. The routes of inclusion and the conditions of learning together].Väitöskirja. Jyväskylä studies in education, psychology and social research 412 .

Moberg, S. (1990). Erityiskasvatuksen erityisyys. Kasvatus [Education] 21,no.2: 241-245.

Moberg, S. (1996). Integraatiokehitys peruskoulun erityisopetuksessa. [The development of integration in the special needs education of the comprehensive school]. In H. Blom, R. Laukkanen, A. Lindström, U. Saresma\& P. Virtanen (eds.) Helsinki: Opetushallitus, 121-136.

Moberg, S. (1998). Erityisopetuksen ja yleisopetuksen integraatio opettajien silmin. [The integration of special needs education and general education through the eyes of the teachers]. In T. Ladonlahti, A. Naukkarinen \& S. Vehmas (eds.) Poikkeava vai erityinen? Erityispedagogiikan monet ulottuvuudet. Jyväskylä: Atena, 136-161. 
Myllykoski, A.-M., Melamies, N., \& Kangas, S. (eds.) (2004). Itsenäistyvä nuori ja AD/HD. Jyväskylä: PS-kustannus.

Naukkarinen, A. (2002). Oppiva koulu oppilaan yksilöllisyyden ohjaajana. [The learning school as the instructor of the pupil's individuality]. In M. Jahnukainen (eds.) Lasten erityishuolto ja -opetus Suomessa. Helsinki: WS Bookwell Oy, 345-355.

Naukkarinen, A. (2005). Laatua erityisopetukseen vai yleisopetukseen? [Quality for special needs education or for general education?]Vuosina 1997-2004 erityisopetuksestatehtyjätutkimuksia. Helsinki: Opetushallitus.

Niemi, A.-M., Mietola, R., \& Helakorpi, J. (2010). Erityisluokka elämänkulussa. [Special needs class in the course of life]. Helsinki: Yliopistopaino.

OPM. (2007). Erityisopetuksenstrategia. [The strategy for special needs education]. Opetusministeriön työryhmämuistioita ja selvityksiä 47.

Peterson, J. M., \& Hittie, M. M. (2003). Inclusive teaching. Creating effective schools for all learners. Boston: Prentice Hall.

Pulkkinen, L. (2002). Mukavaa yhdessä. Sosiaalinen alkupääoma ja lapsen sosiaalinen kehitys. [Having fun together. Social starting capital and social development of the child]. Jyväskylä: PS-kustannus.

Puro, E. (2005). Erityisopetukseen otettujen ja siirrettyjen oppilaiden kouluviihtyvyys. [The school enjoyment of the pupils admitted and transferred to the special needs education]. In E. Korkeakoski (eds.) Koulutuksen perusturva ja oppimisen tuki perusopetuksessa. Osaraportti 3, Syventävät artikkelit. Jyväskylä: Jyväskylän yliopistopaino, 82-91. http://www.intermin.fi/lh/biblio.nsf/ (Read 14.12.2010)

Pöyhtäri, V. (2010). Inkluusio - erityisoppilaan uusi mahdollisuus ja haaste koululle. [Inclusion - a new chance for a special needs pupil and a challenge for the school]. Historiallis-hermeneuttinen analyysi erityisoppilaan (vammaisen ja poikkeavan) koulutettavuuskäsityksistä perinteisten ja nykyisten tiedekäsityksien valossa inkluusioon peilaten. Kasvatustieteen lisensiaatintyö. Jyväskylän yliopisto. Kokkolan yliopistokeskus Chydenius.

Saloviita, T. (1998). Erityisopetus kouluorganisaation patologina. [Special needs education as the pathologist of the school organization]. In T. Ladonlahti, A. Naukkarinen \& S. Vehmas (eds.) Poikkeava vai erityinen. Helsinki: Atena, 162-181.

Saloviita, T. (2006). Erityisopetus ja inkluusio. Kasvatus [Education], 37(4), 326-342.

Sindelar, P. T. Shearer, D. K., Yendol-Hoppey, D., \& Liebert, T. W. (2006). The Sustainability of inclusive school reform. Exceptional Children, 72(3), 317-331. http://dx.doi.org/10.1177/001440290607200304

Skårbrevik, K. J. (2005). The quality of special education for students with special needs in ordinary classes. European Journal of Special Needs Education, 20(4), 387-401. 
http://dx.doi.org/10.1080/08856250500268601

Stainback, S., \& Stainback, W. (1997). Inclusion. A guide for educators. Baltimore: Brookes.

Teittinen, A. (2003). Perusopetuksen inkluusiopolitiikan lähtökohtia. [Starting points of inclusion policy in the basic education]. Kotu-raportteja 2/2003. Helsinki: Kehitysvammaliiton tutkimusyksikkö Kotu. Kehitysvammaliitto ry.

Thomas, G., \& Vaughan, M. (2004). Inclusive education. Maidenhead: Open University Press.

Tilastokeskus (2010). Erityisopetukseen siirretyt peruskoulun oppilaat 1995-2010.[Comprehensive school pupil tranfers to special needs education 1995-2010.] http://www.tilastokeskus.fi/til/erop/2010/erop_2010_2011-06-09_tau_001_fi.html(Read 15.6.2011)

Wilson, R. (2003). Special Educational Needs in the Early Years. London: Routledge Falmer. http://dx.doi.org/10.4324/9780203404973

Voutilainen, A., Häyrinen, T., \& Iivanainen, M. (2000). Inlärningssvårigheter, hur de yttrar sig, diagnostisering, förekomst och orsaker. In K. Stranden (eds.) Ingen dumblom, bara annorlunda. Helsinki: Stakes, 12-16.

Välijärvi, J., \& Heikkinen L.T. (2012). Peer-group mentoring and the culture of teacher education in Finland. In L.T. Heikkinen, H. Jokinen \& P. Tynjälä (eds.), Peer-Group mentoring for Teacher Development. London and New York: Routledge, 31-40.

Yin, R. K. (2003). Case Study Research.Design and Methods. Applied Social research Methods Series, 5. London: Sage. 